\title{
CONTINUOUS GRADATIONS AMONG PRIMARY KIMBERLITIC, CARBONATITIC, MELILITITIC, AND KOMATIITIC MELTS IN EQUILIBRIUM WITH GARNET LHERZOLITE AT 3-8 GPA
}

\author{
Gudmundur H. Gudfinnsson ${ }^{1}$ and Dean C. Presnall ${ }^{1,2}$ \\ ${ }^{I}$ Geophysical Laboratory, USA; ${ }^{2}$ University of Texas at Dallas, USA
}

\section{INTRODUCTION}

Geochemical evidence suggests that at least some kimberlite (Smith et al., 1985) and carbonatite magmas (Nelson et al., 1988; Harmer and Gittins, 1998) are derived by melting of the asthenospheric mantle. On account of the high concentrations of incompatible trace elements in carbonatites and kimberlites, generation by very small degrees of melting is inferred (Nelson et al., 1988). Experiments to determine the phase equilibria involving incipient melting of upper mantle peridotite are technically a difficult task. Because of the small amount of melt present, it is hard to maintain equilbrium during the experiments, and the melts generated are almost invariably modified upon quenching and impossible to analyze because of their very small volume. However, by reducing the number of components, and hence the variance of the system, the task becomes reasonable in scope. The system $\mathrm{CaO}-$ $\mathrm{MgO}-\mathrm{Al}_{2} \mathrm{O}_{3}-\mathrm{SiO}_{2}-\mathrm{CO}_{2}$ (CMAS- $\left.\mathrm{CO}_{2}\right)$ is a realistic model system to investigate the phase equilbria involving mantle peridotite in equilibrium with $\mathrm{CO}_{2}$ bearing melts (Dalton and Presnall, 1998a,b). In the CMAS- $\mathrm{CO}_{2}$ system, the garnet lherzolite phase assemblage coexists with melt along a divariant surface in P-T space (Fig. 1). On the low-temperature side, the divariant surface is bounded by a univariant solidus curve, along which the garnet lherzolite phase assemblage is joined by dolomite or magnesite. On the high-temperature side, the surface is delimited by the $\mathrm{CO}_{2}$-free garnet lherzolite solidus. As the P-T slope of the $\mathrm{CO}_{2}$-free solidus is considerably greater than that of the carbonate-bearing solidus, the temperature difference between these curves increases with pressure. At a fixed pressure and temperature, the garnet lherzolite plus liquid phase assemblage is invariant and compositions of all phases are uniquely defined, independent of the bulk composition of the system. This means that with proper starting compositions the phase equilibrium data can be obtained in experiments with large amount of melt present. Once the phase equilibrium data have been acquired, algebraic methods allow calculation of melting paths for any arbitrary mantle composition in the CMAS- $\mathrm{CO}_{2}$ system (Presnall, 1986), including melting paths where very small amounts of liquid are present.

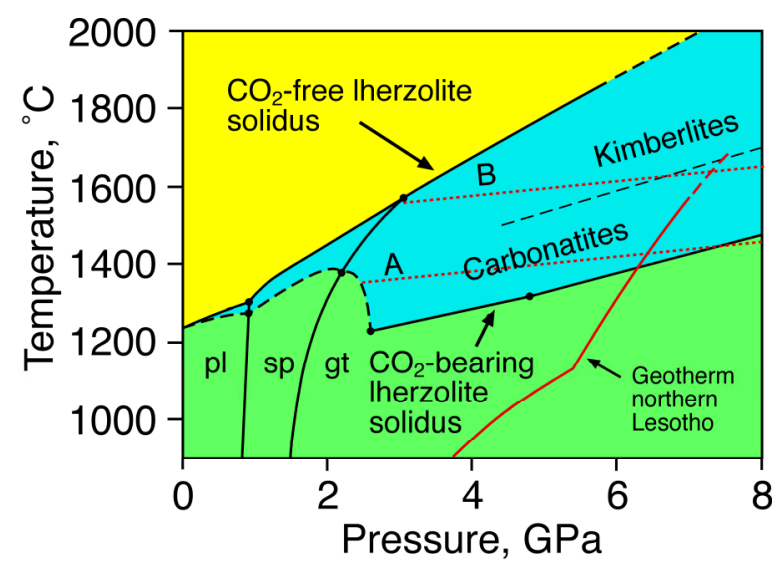

Figure 1: Pressure-temperature diagram for the solidus of plagioclase, spinel and garnet lherzolite in the $\mathrm{CMAS}-\mathrm{CO}_{2}$ system under $\mathrm{CO}_{2}$-free and $\mathrm{CO}_{2}$-bearing conditions. The point on the $\mathrm{CO}_{2}$-bearing solidus curve at about $5 \mathrm{GPa}$ denotes the transition from dolomite-bearing garnet lherzolite to magnesite-bearing garnet lherzolite. The black dashed line indicates the approximate division between carbonatitic and kimberlititc melt in the system. The dashed red lines marked $\mathrm{A}$ and $\mathrm{B}$ are adiabats discussed in the text with a slope of $15^{\circ} \mathrm{C} / \mathrm{GPa}$ and potential temperatures of $1310^{\circ} \mathrm{C}$ and $1510^{\circ} \mathrm{C}$, respectively. The red solid curve is the geotherm for northern Lesotho determined by Finnerty and Boyd (1987). Modified after Presnall et al. (2002).

In earlier experiments in the $\mathrm{CMAS}-\mathrm{CO}_{2}$ system, Dalton and Presnall (1998a,b) determined the carbonate-bearing solidus at 3-7 GPa (Dalton and Presnall, 1998a) and the 6-GPa isobar (Dalton and Presnall, 1998b) on the divariant surface with garnet lherzolite in equilibrium with $\mathrm{CO}_{2}$-bearing melt. In this paper, we expand these results to include a determination of melting relations throughout the P-T region bounded by the 3- and 8-GPa isobars and the two solidus curves. This provides a fuller picture of how melt compositions change with $\mathrm{P}$ and $\mathrm{T}$. Our experimental data confirm the continuous gradations beween carbonatites, kimberlites, and komatiites 


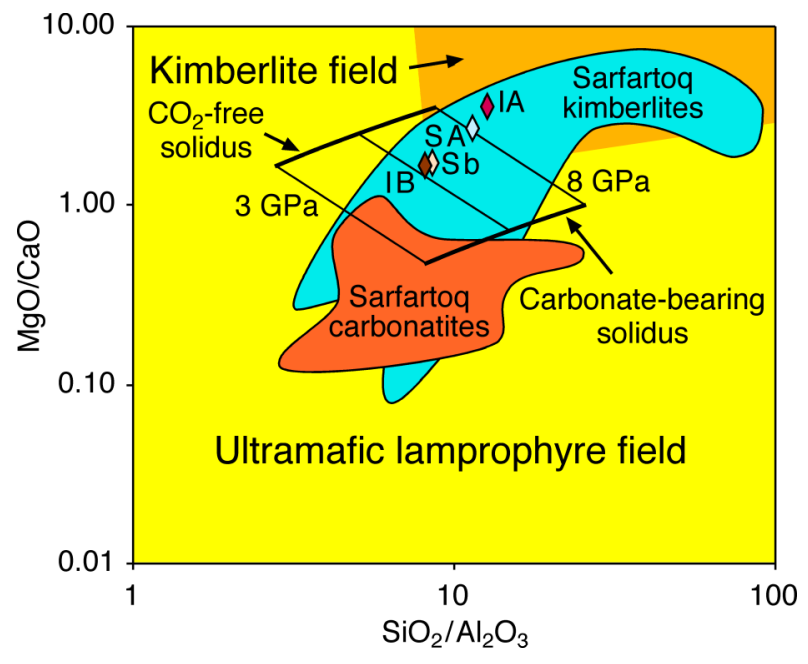

Figure 2: Compositions of melts generated in equilibrium with garnet lherzolite in the CMAS- $\mathrm{CO}_{2}$ system shown in a discrimination diagram for kimberlites and ultramafic lamprophyres (Rock, 1991). For clarity, only three isobars (3-, 5-, and 8-GPa) are shown. The fields for the kimberlites and carbonatites from the Sarfartoq region in west Greenland are based on the unpublished data of L.M. Larsen. The average compositions of IA and IB kimberlites are from Smith et al. (1985). SA and $\mathrm{Sb}$ are the average compositions of kimberlites from Kimberley, South Africa (Clement, 1982) and Siberian kimberlites (Ilupin and Lutz, 1971), respectively.

observed by Dalton and Presnall (1998b), but, in addition, we note the gradation of kimberlite compositions toward melilitite compositions at the lowpressure end of the data.

\section{METHODS}

The melting experiments were conducted at the Geophysical Laboratory using a multianvil apparatus. Methods for preparing starting mixtures, experimental procedures, and treatment of run products are essentially the same as described by Dalton and Presnall (1998a). All crystalline phases and quenched melts in polished sections were analyzed using a JEOL JXA-8800 electron microprobe at the Geophysical Laboratory. Analyses were reduced using the ZAF correction routine and the amount of $\mathrm{CO}_{2}$ in the melts was calculated by difference. All phase compositions have been parameterized as a function of $\mathrm{P}$ and $\mathrm{T}$, which then allows calculation of melting paths according to the algebraic methods of Presnall (1986).

\section{MELT COMPOSITIONS}

On the high-pressure side of the divariant surface containing melts in equilibrium with garnet lherzolite in the CMAS- $\mathrm{CO}_{2}$ system, the compositions of melts change continuously from relatively silica-rich (about 47 to $>52 \mathrm{wt} \% \mathrm{SiO}_{2}$ ) komatiitic melts on the $\mathrm{CO}_{2}$-free solidus through kimberlitic compositions and, finally, carbonatitic compositions with decreasing temperature. In Fig. 1, the division between carbonatites and kimberlites is placed where the amount of $\mathrm{CO}_{2}$ in the liquid translates to about $50 \%$ modal carbonate, which is the minimum amount in carbonatites as proposed by Woolley et al. (1996). At low pressures, the melts on the carbonate-bearing solidus are also carbonatitic, but with increasing temperature the melts become significantly more aluminous and less magnesian than at higher pressures, and at about $3 \mathrm{GPa}$ the melts are more akin to melilitites than kimberlites. Fig. 2 depicts how the melt compositions change with $\mathrm{MgO} / \mathrm{CaO}$ and $\mathrm{SiO}_{2} / \mathrm{Al}_{2} \mathrm{O}_{3}$. This discrimination diagram for kimberlites and ultramafic lamprophyres (Rock, 1991) shows that with increasing pressure and temperature the melt compositions partly extend into the kimberlite field. However, melts generated near the carbonated solidus do not become kimberlitic at any pressure in the range of our experiments. As the $\mathrm{CO}_{2}$ content of melts along the carbonate-bearing solidus changes very little with pressure, this feature is not likely to change for a large range of pressure higher than in our experiments, provided the phase assemblage remains the same.

\section{Carbonatites}

At carbonate saturation, the melts coexisting with garnet lherzolite contain $40-45 \mathrm{wt} \% \mathrm{CO}_{2}$, and only 5-6 wt $\% \mathrm{SiO}_{2}$ and $<1 \mathrm{wt} \% \mathrm{Al}_{2} \mathrm{O}_{3}$ (Dalton and Presnall, 1998a). Carbonatite melts in the CMAS- $\mathrm{CO}_{2}$ system have $\mathrm{CaO} /(\mathrm{CaO}+\mathrm{MgO})=0.5-0.7$, a range similar to $\mathrm{CaO} /\left(\mathrm{CaO}+\mathrm{MgO}+\mathrm{FeO}+\mathrm{Fe}_{2} \mathrm{O}_{3}+\mathrm{MnO}\right)$ ratios for natural magnesiocarbonatites and ferrocarbonatites (Woolley and Kempe, 1989). The Sarfartoq carbonatites from west Greenland (L.M. Larsen, unpublished data) plot mostly near the low-pressure end of the carbonate-bearing solidus. As noted by Dalton and Presnall (1998b), their large range is not surprising considering that they are whole rock compositions, and thus do not necessarily represent primary liquid compositions. 


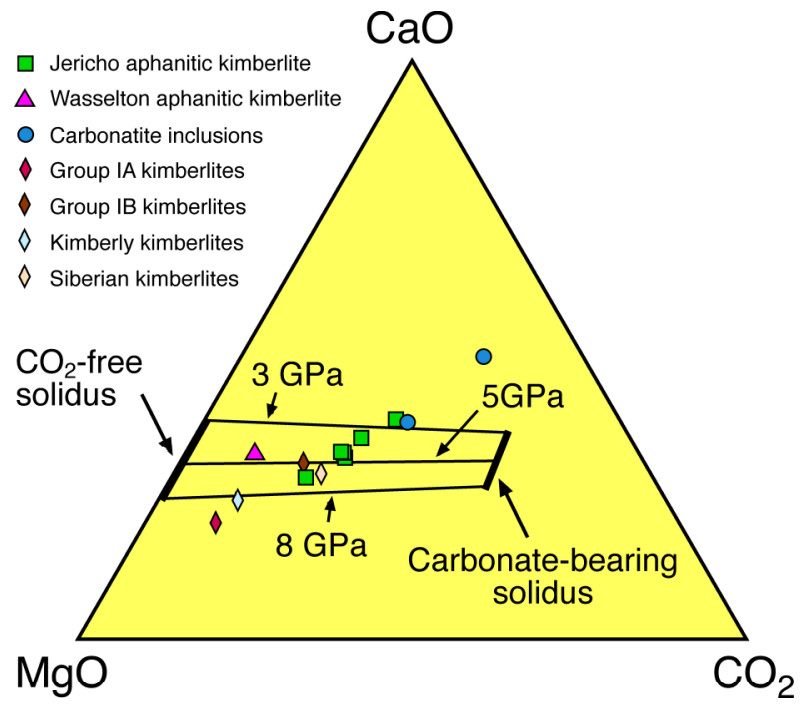

Figure 3: Compositions of aphanitic kimberlites from Jericho pipe, Canada (localities JD61 and JD82) (Price et al., 2000) and Wasselton, South Africa (Shee, 1986), and carbonatitic inclusions from Lac de Gras, Canada (van Achterbergh et al., 2002) in comparison with melts generated in equilibrium with garnet lherzolite in the CMAS- $\mathrm{CO}_{2}$ system and average kimberlite compositions (see Fig. 2 for references).

\section{KIMBERLITES}

Melts analogous to kimberlites are generated at more elevated temperatures than carbonatites and hence higher degrees of melting. Compositions resembling group IB kimberlites (Smith et al., 1985) are generated at pressures around 5-6 GPa whereas the compositions of group IA kimberlites (Smith et al., 1985) are consistent with generation at greater depths at pressures around $10 \mathrm{GPa}$ (Fig. 2). The average compositions of kimberlites from Kimberley, South Africa (Clement, 1982) and of Siberian kimberlites (Ilupin and Lutz, 1971) are also consistent with generation in the same pressure range. The kimberlites of the Sarfartoq region in west Greenland (L.M. Larsen, unpulished data) have a large range in composition, a range that partly overlaps that of the contemporaneous carbonatites from the same area (Fig. 2). Although the large compositional spread of these whole rock compositions allows only a rough comparison with our liquid compositions, the compositional range of the Sarfartoq kimberlites suggests that some kimberlites could be generated at still higher pressures, significantly beyond the range of the experimental data.

\section{COMPARISON WITH PROPOSED CARBONATITIC AND KIMBERLITIC MELT COMPOSITIONS}

The nature of primary kimberlite melts has long been a contentious subject. Kimberlite glasses are never found in nature and it is difficult to identify rocks that unambiguously represent kimberlite melts. A few examples of aphanitic kimberlites that retain considerable amounts of $\mathrm{CO}_{2}$ have been proposed as possibly having compositions close to primitive kimberlite melts. This includes kimberlites from Wasselton mine, South Africa (Shee, 1986; Edgar et al., 1988; Edgar and Charbonneau, 1993) and Jericho pipe, Canada (Price et al., 2000). In Figs. 3, 4, and 5 the compositions of these suspected primitive kimberlite melts have been plotted along with melt compositions from this study in equilibrium with garnet lherzolite mineralogy. Assuming that the natural compositions are near-primary melts, the Wasselton aphanitic kimberlite is consistent with derivation from about 5-8 GPa. The position of the Jericho aphanitic kimberlites on these diagram is also not inconsistent with the conclusion of Price et al. (2000) that the primary melts for these rocks were generated at a pressure of about $6 \mathrm{GPa}$ or slightly higher. In Figs. 3 and 4, the Jericho aphanitic kimberlites form a trend that appears consistent with olivine control. However, Fig. 5 shows that $\mathrm{SiO}_{2} / \mathrm{Al}_{2} \mathrm{O}_{3}$ is very similar in all the samples, or even increases slightly, with decreasing $\mathrm{MgO} / \mathrm{CaO}$, contrary to what one would expect for an olivine control line. An alternative explanation is that the compositional variation is controlled by the addition and/or removal of calcite.

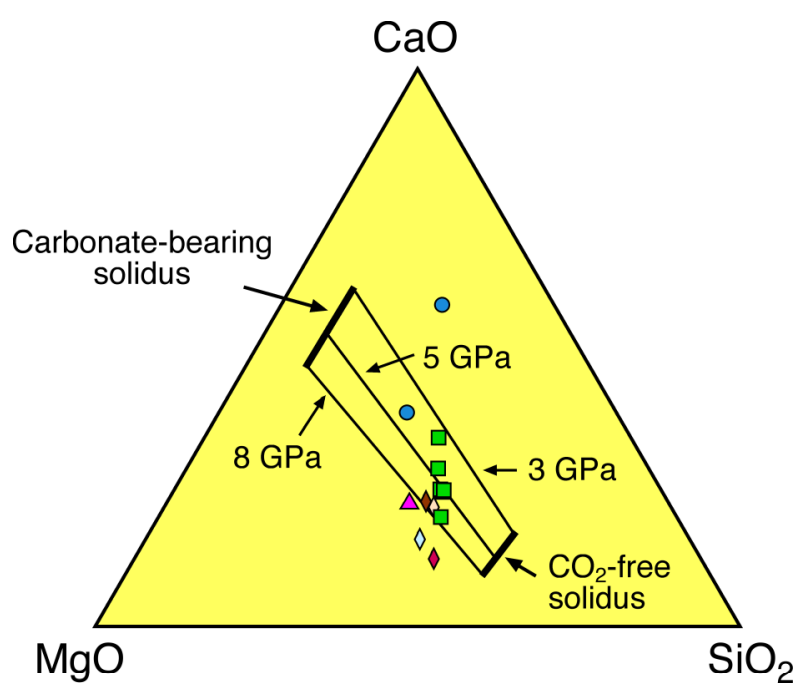

Figure 4: See Fig. 3 for caption and legend. 


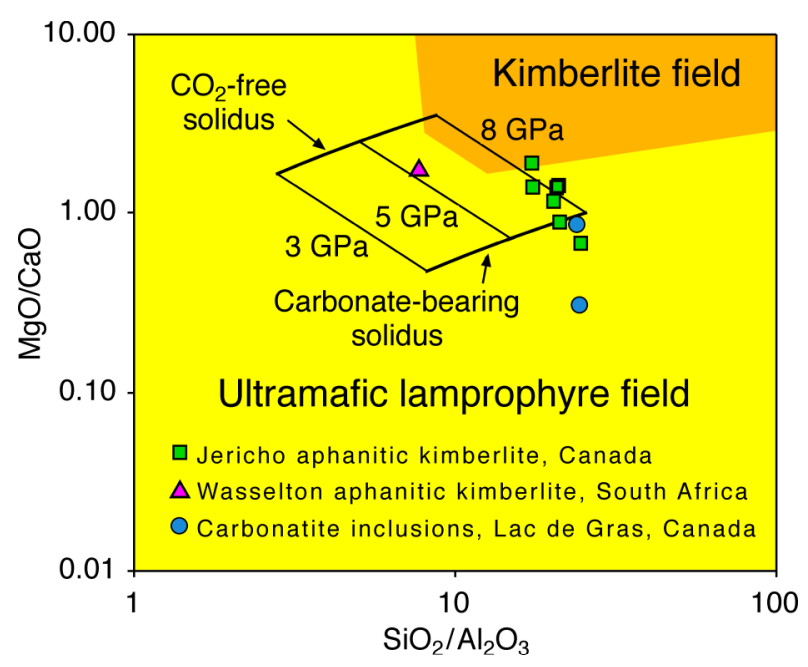

Figure 5: Discrimination diagram for kimberlites and ultramafic lamprophyre (Rock, 1991) showing compositions of aphanitic kimberlites from Jericho pipe, Canada (localities JD69 and JD82) (Price et al., 2000) and Wasselton mine, Kimberley, South Africa (Shee, 1986), and carbonatitic inclusions from Lac de Gras, Canada (van Achterbergh et al., 2002) in comparison with melts generated in equilibrium with garnet lherzolite in the CMAS- $\mathrm{CO}_{2}$ system.

Van Achterbergh et al. (2002) describe inclusions in diopside macrocrysts in the Lac de Gras kimberlite in Canada that have carbonatite composition. The generation of the alleged carbonatite melts may have been temporally linked to the kimberlite eruption. Considering the challenge of analyzing the assemblage of microscopic minerals and the potential for fractionation, the compositions of these inclusions bear surprisingly strong resemblance to melts generated in the 3-8 $\mathrm{GPa}$ pressure range close to the boundary between carbonatites and kimberlites in the CMAS- $\mathrm{CO}_{2}$ system (Figs. 3, 4, and 5). It should be noted that, as expected, the inclusions have very small amounts of $\mathrm{Al}_{2} \mathrm{O}_{3}\left(<1\right.$ wt\%), which means that $\mathrm{SiO}_{2} / \mathrm{Al}_{2} \mathrm{O}_{3}$ in Fig. 5 is sensitive to relatively small uncertainties in $\mathrm{Al}_{2} \mathrm{O}_{3}$. Interestingly, there are strong similarities between the compositions of the carbonatite inclusions and the Jericho aphanitic kimberlites, a further evidence for the gradation between kimberlite and carbonatite melts in the mantle.

\section{MELTING PATHS}

A mantle material carrying only trace amount of carbonate will start to melt at a temperature hundreds of degrees lower than the volatile-free solidus of the mantle (Presnall et al., 2002). Consider, for example, melting of the magnesite-bearing mantle that upwells along adiabat $\mathrm{A}$ in Fig. 1. This adiabat, which is close to an estimated average adiabat beneath mid-ocean ridges (Presnall et al., 2002), intersects the solidus at about $7 \mathrm{GPa}$ at a temperature about $500^{\circ} \mathrm{C}$ lower than the volatile-free solidus. The melting path follows the carbonate-bearing solidus for a very narrow pressure interval until magnesite is exhausted, at which point it enters the divariant surface. Even assuming a relatively carbon-rich mantle with $0.15 \mathrm{wt} \% \mathrm{CO}_{2}$, this will happen after only about $0.3-0.4 \%$ melting. Because of the small amount of liquid being generated, an isentropic melting path follows a solid adiabat very closely. The melt composition is magnesiocarbonatite with slowly increasing silica content and decreasing $\mathrm{CO}_{2}$ content as pressure decreases. At $3 \mathrm{GPa}$ the liquid is still carbonatitic with about $30 \mathrm{wt} \% \mathrm{CO}_{2}$ after nearly $0.5 \%$ melting. Therefore, kimberlitic melt is not generated along this adiabat in the CMAS- $\mathrm{CO}_{2}$ system, but with an elevated geotherm, such as adiabat B in Fig. 1 , a larger range of compositions results. In this case, melting starts at a pressure considerably higher than 8 $\mathrm{GPa}$ and the melting path leaves the carbonatite field and passes into the kimberlite field at about $7 \mathrm{GPa}$. If the total amount of $\mathrm{CO}_{2}$ in the system is $0.15 \mathrm{wt} \%$, the amount of melt at this point is about $0.6-0.7 \%$. At lower pressures the melt becomes melilititic and, finally, at below $3 \mathrm{GPa}$, komatiitic or picritic.

On the basis of the application of geothermobarometry for mantle xenoliths, Finnerty and Boyd (1987) determined the mantle geotherm beneath Lesotho at the time of kimberlite magmatism (Fig. 1), and concluded that the xenoliths came from a pressure of up to $7 \mathrm{GPa}$. Extrapolation of this geotherm yields temperatures in the kimberlite field at just below $8 \mathrm{GPa}$, a pressure slightly higher than the maximum Finnerty and Boyd (1987) estimated for the Lesotho xenoliths. Thus, our data are consistent with generation of the Lesotho kimberlite melts at pressures just above the maximum xenolith depths.

\section{THE EFFECT OF $\mathrm{H}_{2} \mathrm{O}$}

Components other than $\mathrm{CaO}, \mathrm{MgO}, \mathrm{Al}_{2} \mathrm{O}_{3}, \mathrm{SiO}_{2}$, and $\mathrm{CO}_{2}$ are all, except $\mathrm{FeO}$ and $\mathrm{H}_{2} \mathrm{O}$, in such a low abundance that their effect on the phase relations at the melting of garnet lherzolite is likely to be minor. In spite of its abundance, the effect of $\mathrm{FeO}$ on the phase relations is also likely to be relatively small (Gudfinnsson and Presnall, 2000). Results of experiments on the melting of lherzolite indicate that the effect of modest amounts of water on the phase relations is small (Gaetani and Grove, 1998) and likely 
to be greatly subordinate to the effect of $\mathrm{CO}_{2}$. In contrast, the effect of water on the solidus temperature could be considerable (Gaetani and Grove, 1998). From an analysis of several kinds of experimental data, Gudfinnsson and Presnall (2002) found that the soliduslowering effect of water is on the order of $25-60^{\circ} \mathrm{C}$ per each $1 \mathrm{wt} \%$ increase in the $\mathrm{H}_{2} \mathrm{O}$ content of the melt. The aphanitic kimberlites from Jericho pipe contain about 5-7 wt $\% \mathrm{H}_{2} \mathrm{O}$, which is thought to represent the primary water content of the kimberlites (Price et al., 2000), and carbonatites could carry comparable amounts of water (Le Bas, 1981). Hence, the amount of water present in natural kimberlite and carbonatite magmas indicates that they could be produced at temperatures up to $200-300^{\circ} \mathrm{C}$ lower than the solidus in the CMAS- $\mathrm{CO}_{2}$ system. Kimberlite melts could then be produced by melting of upwelling $\mathrm{CO}_{2}$-bearing garnet lherzolite under conditions where the adiabat is not much hotter than the average MORB mantle adiabat, depending on the water content. As a corollary, carbonatite and kimberlite melts may be ubiquitous at depth wherever the mantle upwells, and, because these kinds of melts carry very high concentrations of incompatible elements, this could have a profound effect on the trace element signatures of basalts (Presnall et al., 2002).

\section{REFERENCES}

Van Achterbergh, E., Griffin, W.L., Ryan, C.G., O’Reilly, S.Y., Pearson, N.J., Kivi, K., Doyle, B.J., 2002. Subduction signature for quenched carbonatites from the deep lithosphere. Geology 30, 743-746.

Clement, C.R., 1982. A comparative geological study of some major kimberlite pipes in the northern Cape and Orange Free State. Ph.D. Thesis, University of Cape Town, South Africa.

Dalton, J.A., Presnall, D.C., 1998a. Carbonatitic melts along the solidus of model lherzolite in the system $\mathrm{CaO}$ $\mathrm{MgO}-\mathrm{Al}_{2} \mathrm{O}_{3}-\mathrm{SiO}_{2}-\mathrm{CO}_{2}$ from 3 to $7 \mathrm{GPa}$. Contrib. Mineral. Petrol. 131, 123-135.

Dalton, J.A., Presnall, D.C., 1998b. The continuum of primary carbonatitic-kimberlitic melt compositions in equilibrium with lherzolite: data from the system CaO-MgO- $-\mathrm{Al}_{2} \mathrm{O}_{3}-\mathrm{SiO}_{2}-\mathrm{CO}_{2}$ at 6 GPa. J. Petrol. 39, 1953-1964.

Edgar, A.D., Charbonneau, H.E., 1993. Melting experiments on a $\mathrm{SiO}_{2}$-poor, $\mathrm{CaO}$-rich aphanitic kimberlite from 5$10 \mathrm{GPa}$ and their bearing on sources of kimberlite magmas. Am. Mineral. 78, 132-142.

Edgar, A.D., Arima, M., Baldwin, D.K., Bell, D.R., Shee, S.R., Skinner, E.M.W., Walker, E.C., 1988. Highpressure-high-temperature melting experiments on a $\mathrm{SiO}_{2}$-poor aphanitic kimberlite from the Wasselton mine, Kimberley, South Africa. Am. Mineral. 73, 524533.
Finnerty, A.A., Boyd, F.R., 1987. Thermobarometry for garnet peridotites: basis for the determination of thermal and compositional structure of the upper mantle. In: Nixon, P.H. (Ed.), Mantle Xenoliths. John Wiley \& Sons Ltd, Chichester, UK, pp. 381-402.

Gaetani, G.A., Grove, T.L., 1998. The influence of water on melting of mantle peridotite. Contrib. Mineral. Petrol. 131, 323-346.

Gudfinnsson, G.H., Presnall, D.C., 2000. Melting behaviour of model lherzolite in the system $\mathrm{CaO}-\mathrm{MgO}-\mathrm{Al}_{2} \mathrm{O}_{3}$ $\mathrm{SiO}_{2}-\mathrm{FeO}$ at 0.7-2.8 GPa. J. Petrol. 41, 1241-1269.

Gudfinnsson, G.H., Presnall, D.C., 2002. The minimum potential temperature of the Hawaiian mantle is about $1420^{\circ} \mathrm{C}$. Eos Trans. AGU 83 (47), Fall Meeting Suppl., Abstract V52D-06.

Harmer, R.E., Gittins, J., 1998. The case for primary, mantlederived carbonatite magma. J. Petrol. 39, 1895-1903.

Ilupin, I.P., Lutz, B.G., 1971. The chemical composition of kimberlite and questions on the origin of kimberlite magmas. Sovetskaya Geologiya 6, 61-73 (in Russian).

Le Bas, M.J., 1981. Carbonatite magmas. Mineral. Mag. 44, $133-140$.

Nelson, D.R., Chivas, A.R., Chappell, B.W., McCulloch, M.T., 1988. Geochemical and isotopic systematics in carbonatites and implications for the evolution of ocean-island sources. Geochim. Cosmochim. Acta 52, $1-17$.

Presnall, D.C., 1986. An algebraic method for determining equilibrium crystallization and fusion paths in multicomponent systems. Am. Mineral. 71, 10611070.

Presnall, D.C., Gudfinnsson, G.H., Walter, M.J., 2002. Generation of mid-ocean ridge basalts at pressures from 1 to $7 \mathrm{GPa}$. Geochim. Cosmochim. Acta 66, 2073-2090.

Price, S.E., Russell, J.K., Kopylova, M.G., 2000. Primitive magma from the Jericho pipe, N.W.T., Canada: constraints on primary kimberlite melt chemistry. J. Petrol. 41, 789-808.

Rock, N.M.S, 1991. Lamprophyres. Blackie, Glasgow.

Shee, S.R., 1986. The petrogenesis of the Wasselton mica kimberlites, Kimberley, South Africa. Ph.D. Thesis, University of Cape Town, Cape Town, South Africa.

Smith, C.B., Gurney, J.J., Skinner, E.M.W., Clement, C.R., Ebrahim, N., 1985. Geochemical character of southern African kimberlites: a new approach based on isotopic constraints. Tran. geol. Soc. S. Afr. 88, 267-280.

Woolley, A.R., Kempe, D.R.C., 1989. Carbonatites: nomenclature, average chemical compositions, and element distribution. In: Bell, K. (Ed.), Carbonatites: genesis and evolution. Unwin Hyman Ltd, London, UK, pp. 1-14.

Woolley, A.R., Bergman, S.C., Edgar, A.D., Le Bas, M.J., Mitchell, R.H., Rock, N.M.S., Scott Smith, B.H., 1996. Classification of lamprophyres, lamproites, kimberlites, and the kalsilitic, melilitic, and leucitic rocks. Can. Mineral. 34, 175-186.

Contact: GH Gudfinnsson, 5251 Broad Branch Rd, NW, Washington, DC 20015-1305, USA, E-mail: g.gudfinnsson@gl.ciw.edu 